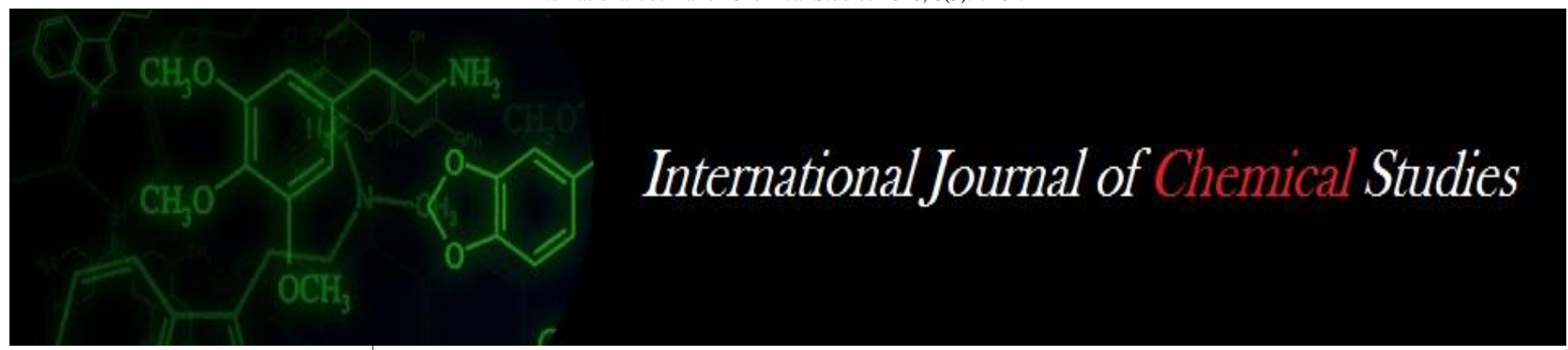

P-ISSN: 2349-8528

E-ISSN: 2321-4902

www.chemijournal.com

IJCS 2020; 8(5): 720-724

(C) 2020 IJCS

Received: 28-07-2020

Accepted: 30-08-2020

Priyanka Choudhary

M.Sc. Student, Department of

Genetics \& Plant Breeding,

MPUAT, Udaipur, Rajasthan,

India

\section{Hemlata Sharma}

Assistant Professor, Department of Genetics \& Plant Breeding, MPUAT, Udaipur, Rajasthan, India

Sanjay Kumar Sanadya PhD Scholar, Department of Genetics \& Plant Breeding, CSK HP Agriculture University, Palampur, Himachal Pradesh, India

\section{NS Dodiya}

Professor, Department of Genetics \& Plant Breeding, MPUAT, Udaipur, Rajasthan, India

\section{Vimal Bishnoi}

M.Sc. Student, Rajasthan College of Agriculture, MPUAT,

Udaipur, Rajasthan, India
Corresponding Author: Priyanka Choudhary M.Sc. Student, Department of Genetics \& Plant Breeding, MPUAT, Udaipur, Rajasthan, India

\section{Combining ability for agronomic and quality traits in Indian mustard}

\author{
Priyanka Choudhary, Hemlata Sharma, Sanjay Kumar Sanadya, NS \\ Dodiya and Vimal Bishnoi
}

DOI: https://doi.org/10.22271/chemi.2020.v8.i5j.10386

\begin{abstract}
The present study was carried out among forty-nine Indian mustard genotypes involving $\mathrm{F}_{1} \mathrm{~s}$, their parents and 2 checks developed through Line $\mathrm{x}$ Tester mating design and evaluated at Breeding Research Farm, MPUAT, Udaipur in Rabi-2018 in Randomized Block Design. Results revealed that contribution of General combining ability to total mean squares was higher than that of Specific combining ability for all the traits, providing that additive gene action was more important in their inheritance. The analysis of variance revealed that the mean squares due to genotypes, parents, crosses and parents $v / s$ crosses were significant for all the traits. General combining ability mean squares for lines and testers and Specific combining ability mean squares were significant for most of the traits indicating that both additive and nonadditive gene action were involved in the inheritance of these traits. However, the contribution of General combining ability to total mean squares was higher than that of Specific combining ability for DOF, DOM, NSP, NPB, LMA, LS, SYP HI and OC traits, providing that additive gene action was more important, while non-additive gene action for resting traits. Lines PM-27 and SKM-1313 had positive General combining ability effects for seed yield per plant and negative General combining ability effects for oil content. These lines can be used as parents to create synthetic varieties or hybrids.
\end{abstract}

Keywords: Indian mustard, breeding method, combining ability, gene action

\section{Introduction}

Indian mustard [Brassica juncea (L.) Czern \& Coss] is an important oil seed crop of the world that is belongs to brassicaceae family. Indian mustard is a natural amphidiploid $(2 \mathrm{n}=4 \mathrm{x}=36)$ which is derived from natural crossing between Brassica campestris $(2 \mathrm{n}=20)$ and Brassica nigra $(2 \mathrm{n}=16)\left(\right.$ Nagaheru U, 1935) ${ }^{[8]}$. It originated in Asia with its major center of diversity in China (Vaughan, 1977) ${ }^{[17]}$. It was introduced in India from China. It accounts for more than $75 \%$ of the total area under rapeseed-mustard cultivation in India (Chaurasiya et al., 2018) ${ }^{[3]}$ because of its wider adaptability and comparative tolerance to biotic and abiotic stresses. Indian mustard is largely self-pollinated (85-90\%) crop but owing to insects, especially the honeybees, the extent of cross-pollination varies from 4.0 to $16.6 \%$ (Rambhajan et al., 1991) [10]. Mustard is a Rabi season crop of temperate region, which requires relatively cool temperature. The oil content varies from 37 to $49 \%$ (Bhowmik et al., 2014) ${ }^{[2]}$. Its seed contain nutritional value viz., carbohydrates $4.51 \mathrm{~g}$, sugar $1.41 \mathrm{~g}$, dietary fiber $2 \mathrm{~g}$, fat $0.47 \mathrm{~g}$ and protein $2.56 \mathrm{~g}$ per $100 \mathrm{~g}$ (Tyagi and Singh, 2016) ${ }^{[16]}$. Mustard seed is largely crushed for edible oil, which is perhaps the cheapest source of oil in our daily diet and also utilized as a condiment for pickles preparation, medicinal uses and has industrial applications like softening leather. The green leaves of young plants are used as green vegetables as they supply enough sulphur and minerals in the diet. The major rapeseed-mustard producing countries are Canada, China, Germany and France. Oilseeds occupy a place of prime importance in Indian economy that is evident from the impact created by yellow revolution. India occupies the first position in area and second position in production of mustard after China. In India, it occupies an area of about $6.0 \mathrm{M}$ ha. with 8.32 Million tones production and $1397 \mathrm{~kg} / \mathrm{ha}$ productivity (Directorate of Economics and Statistics, 2018) ${ }^{[1]}$. Rajasthan is the largest producer of rapeseed-mustard followed by Madhya Pradesh, Uttar Pradesh, Haryana, West Bengal, Gujarat and Assam. In Rajasthan, mustard occupies 2.33 Mha, 3.40 MT, $1453 \mathrm{Kg} / \mathrm{ha}$ area, production 
and productivity, respectively (Directorate of Economics and Statistics, 2018) ${ }^{[1]}$. Development of the hybrids in Mustard is important to increase yield per se and enhance quality traits performance. Combining ability analysis is one of the powerful tools to test the value of parental lines to produce superior hybrids and valuable recombinants (Singh et al., 2013) ${ }^{[11]}$. Therefore, selection is carried out based on per se performance and combining ability of the parents. This genetic information can be obtained by different mating design including line $\times$ tester (Kempthorne 1957) ${ }^{[5]}$. The objectives of this study were to estimate combining ability of Indian mustard inbred lines for yield and its related traits and identify superior mustard hybrids for oil content, yield and yield components. Combining ability studies emphasized the predominant effect of GCA on yield and most of the yield components indicating the importance of additive gene action (Gupta et al., 2006) ${ }^{[4]}$. Meena et al. (2015) ${ }^{[7]}$ reviewed the evidences for the presence of significant SCA effects for seed yield and oil content indicating importance of non-additive gene action.

\section{Materials and Methods}

Eleven mustard inbred lines were crossed with three testers' viz., PM-27, PM-28, and Pusa Vijay during Rabi 2017 to develop thirety-three crosses. Thus, the experimental material comprised of $33 \mathrm{~F}_{1}$ crosses, 14 parents and two checks viz., Pusa Mustard 25 and DRMRIJ-31 were sown in Randomized Block Design with three replications maintaining crop geometry of $30 \times 10 \mathrm{~cm}$. Experiment was evaluated at Breeding Research farm, MPUAT (Maharana Pratap University of Agriculture and Technology), Udaipur during Rabi 2018. The observations were recorded for fourteen characters viz., DOF, DOM, PH, NPB, NSB, LMA, NSP, LS, NSS, SYP, TW, BYP, HI and OC among them DOF and DOM observations were recorded on whole plot basis. Oil content was estimated by using Soxhlet's method (Soxhlet 1879) ${ }^{[12]}$.

Table 1: Detail of parental genotypes and their source

\begin{tabular}{|c|c|c|}
\hline S. No. & Genotypes & Source of materials \\
\hline 1 & SKM-1214 & SDAU, Gujarat \\
\hline 2 & SKM-1118 & SDAU, Gujarat \\
\hline 3 & SKM-1013 & SDAU, Gujarat \\
\hline 4 & SKM-939 & SDAU, Gujarat \\
\hline 5 & SKM-445 & SDAU, Gujarat \\
\hline 6 & SKM-1313 & SDAU, Gujarat \\
\hline 7 & SKM-1319 & SDAU, Gujarat \\
\hline 8 & SKM-1328 & SDAU, Gujarat \\
\hline 9 & SKM-1310 & SDAU, Gujarat \\
\hline 10 & SKM-1314 & SDAU, Gujarat \\
\hline 11 & SKM-1033 & SDAU, Gujarat \\
\hline 12 & Pusa Vijay & IARI, Delhi \\
\hline 13 & Pusa Mustard-27 & IARI, Delhi \\
\hline 14 & Pusa Mustard-28 & IARI, Delhi \\
\hline 15 & DRMRIJ-31(C) & DRMR, Bharatpur \\
\hline 16 & Pusa Mustard-25(C) & IARI, Delhi \\
\hline
\end{tabular}

Statistical analysis: The combining ability analysis for line $\mathrm{x}$ tester mating design (LxT) was performed as per method suggested by Kempthorne (1957) ${ }^{[5]}$. The following model was used to estimate general and specific combining ability effects of the $\mathrm{ij}^{\text {th }}$ observations.

$$
Y_{i j k}=\mu+G_{i}+G_{j}+S_{i j}+R_{k}+\Sigma e_{i j k}
$$

\begin{tabular}{|c|c|c|c|}
\hline $\mathrm{Y}_{\mathrm{ijk}}$ & Phenotypic expression of $\mathrm{ij}^{\text {th }}$ genotype in $\mathrm{k}^{\text {th }}$ replication & $\mathrm{i}$ & Varies from $1,2,3, \ldots \ldots$ \\
\hline$\mu$ & Population mean, & $\mathrm{j}$ & Varies from $1,2,3, \ldots . . \mathrm{t}$ \\
\hline $\mathrm{G}_{\mathrm{i}}$ & GCA effects of $\mathrm{i}^{\text {th }}$ line, & $\mathrm{k}$ & Varies from $1,2,3, \ldots . \mathrm{r}$ \\
\hline $\mathrm{G}_{\mathrm{j}}$ & GCA effects of $\mathrm{j}^{\text {th }}$ tester, & $\mathrm{R}_{\mathrm{k}}$ & ${\text { Effect of } \mathrm{k}^{\text {th }} \text { replication }}$ \\
\hline $\mathrm{S}_{\mathrm{ij}}$ & SCA effects of cross between $\mathrm{i}^{\text {th }}$ line and $\mathrm{j}^{\text {th }}$ tester & $\sum \mathrm{e}_{\mathrm{ijk}}$ & $\begin{array}{c}\text { Uncontrolled variation/error associated } \\
\text { with ij cross in } \mathrm{k}^{\text {th }} \text { replication }\end{array}$ \\
\hline
\end{tabular}

\section{Result and Discussion}

\section{Mean Performance of Hybrids}

The inbred line SKM-1033 exhibited maximum mean values for SYP, NPB and NSB. While the line SKM-1314 exhibited maximum mean values for NSP and HI. This line also exhibited minimum mean values for DOF. Line SKM-939 exhibited higher mean values for LMA. Line SKM-1319 exhibited maximum mean values for LS. Line SKM-445 exhibited minimum mean value for DOM. Line SKM-1013 exhibited minimum mean value for PH. The Line SKM-1328 depicted maximum mean values for OC, NSP and NPB. Among the crosses, cross SKM-1118 x PM-27 showed maximum mean value for SYP while the cross SKM-1313 $\mathrm{x}$
PM-28 exhibited maximum mean value for NSP. The cross SKM-1328 x Pusa Vijay exhibited maximum mean values for LS. Cross SKM-1310 x Pusa Vijay showed maximum mean values for NSP, SKM-11319 x PM-28 for TW, SKM-939 x PM-27 for BYP and SKM-1328 x PM-28 for HI. The crosses SKM-1033 x PM-27 exhibited maximum mean values for OC. Among the crosses, cross SKM-1314 x Pusa Vijay exhibited minimum mean values for DOF and $\mathrm{PH}$ and the cross SKM-445 x Pusa Vijay also expressed minimum mean value for DOF. Similarly cross SKM-1328 x Pusa Vijay, exhibited minimum mean values for DOM similar results were observed by Wolko et al. (2019) ${ }^{[18]}$ for some traits in Brassica napus. 
Table 2: Analysis of variance for combining ability for fourteen traits in Indian Mustard

\begin{tabular}{|c|c|c|c|c|c|c|c|}
\hline S. no. & Characters & Rep & Tester & Lines & Crosses & L X T & Error \\
\hline & DF & 2 & 2 & 10 & 32 & 20 & 96 \\
\hline 1 & DOF & 3.73 & $7.44^{* *}$ & $18.19^{* *}$ & $16.59^{* *}$ & $15.57^{* *}$ & 1.44 \\
\hline 2 & DOM & 5.56 & $21.78^{* *}$ & $45.61^{* *}$ & $22.46^{* *}$ & $16.55^{* *}$ & 2.03 \\
\hline 3 & PH & 491.71 & 164.78 & 87.13 & $351.56^{* *}$ & 246.34 & 183.86 \\
\hline 4 & NPB & 0.57 & $1.44^{*}$ & $3.09^{* *}$ & $1.81^{* *}$ & $2.41^{* *}$ & 0.33 \\
\hline 5 & NSB & 2.04 & $7.00^{* *}$ & $7.36^{* *}$ & $22.12^{* *}$ & $15.07^{* *}$ & 0.70 \\
\hline 6 & LMA & 90.06 & $148.98^{* *}$ & $344.27^{* *}$ & $333.44^{* *}$ & $259.33^{* *}$ & 30.17 \\
\hline 7 & NSP & 2216.58 & $19115.44^{* *}$ & $9305.75^{* *}$ & $11306.31^{* *}$ & $10341.88^{* *}$ & 808.90 \\
\hline 8 & LS & 0.29 & $1.12^{* *}$ & $1.12^{* *}$ & $1.11^{* *}$ & $1.30^{* *}$ & 0.10 \\
\hline 9 & NSS & 2.46 & 0.78 & $4.73^{* *}$ & $6.51^{* *}$ & $6.68^{* *}$ & 0.93 \\
\hline 10 & SYP & 4.17 & $21.00^{*}$ & $83.82^{* *}$ & $52.26^{* *}$ & $60.81^{* *}$ & 6.83 \\
\hline 11 & TW & 0.39 & 0.18 & $0.64^{* *}$ & $1.60^{* *}$ & $1.38^{* *}$ & 0.15 \\
\hline 12 & BYP & 47.68 & 10.74 & 104.97 & $248.56^{* *}$ & $245.44^{* *}$ & 69.31 \\
\hline 13 & HI & 7.28 & 11.50 & $81.78^{* *}$ & $90.18^{* *}$ & $114.71^{* *}$ & 9.48 \\
\hline 14 & OC & 1.50 & $4.55^{* *}$ & $8.75^{* *}$ & $9.33^{* *}$ & $9.67^{* *}$ & 0.53 \\
\hline
\end{tabular}

$*, * *$ Significant at $5 \%$ and $1 \%$ level of significance, respectively.

\section{ANOVA for combining ability}

The total variation due to crosses was partitioned into line, tester and line $\times$ tester interaction (Table 2). The mean squares due to hybrids were significant for all the traits. Line mean squares were also significant for all the traits except for $\mathrm{PH}$ and BYP while tester mean squares were not significant for BYP, HI, TW and NSS. Line $\times$ tester mean squares were significant for most traits except PH. Similar results were reported by Patel et al. (2015) ${ }^{[9]}$ and Kumar et al. (2017) ${ }^{[6]}$ in Indian mustard.

\section{Relative Contributions of Mean Squares to Additive and Nonadditive Effects}

The relative importance of mean squares, for additive effect $(\mathrm{GCAm}+\mathrm{GCAf})$, was higher for following traits viz., DOF, DOM, NSP, NPB, LMA, LS, SYP HI and OC traits, compared to the dominance effect (SCA) (Figure 1).

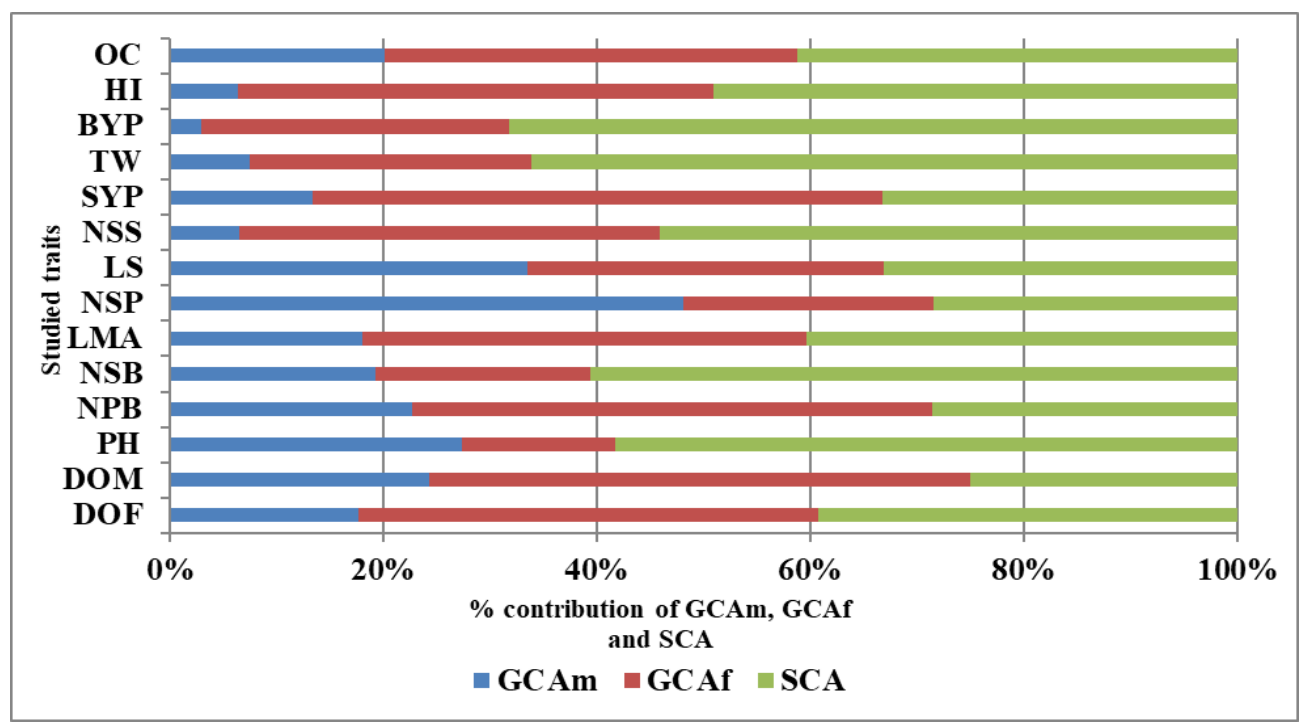

Fig 1: Proportion of total mean squares of studied traits attributable to GCAm, GCAf and SCA

GCA effects accounted for most of the variation observed for most of the traits with more than $50 \%$ of the total genotypic variation among hybrids except for PH, NSB, LMA, NSS, TW and BYP. The overall contribution of GCA mean of squares to the total (GCA+SCA) mean squares varied from $32 \%$ for BYP to $80 \%$ for DOM while SCA varied from $20 \%$ for DOM to $68 \%$ for BYP. The contribution of GCAm was higher than GCAf and SCA for NSP while GCAf was larger than GCAm and SCA mean square for DOF, DOM, NPB, LMA and SYP and the contribution of GCAf was equal GCAm for LS also similar results were observed by Teklewold and Becker (2005) ${ }^{[14]}$ in Ethiopian mustard.

\section{Estimation of General Combining Ability Effects}

The contribution of lines and testers to crosses for traits studied is presented in Table 4. For female lines, significant GCA effects were observed for most of the traits while for male lines significant GCA effects were recorded for DOF, LMA, NSP, TW and BPY. For DOF, the GCA effects varied from -1.79 for SKM-445 to 3.43 for SKM-939. Positive and significant GCA effects for DOF were observed on parental lines SKM-1013 and SKM-939. For DOM, GCA effects ranged from -1.95 for SKM-445 and SKM-1313 to 4.2 for SKM-1310, both positive and negative significant GCA effects were observed. Estimates of GCA effects for PH ranged from -11.83 for SKM-1314 to 16.83 for SKM-445. Out of the 14 parental lines, two showed negative and significant effects whereas one line exhibited positive and significant effects for $\mathrm{PH}$. As per estimates of combining ability, only one line (SKM-1313) expressed positive significant GCA effects for SYP. Among the testers, only one tester (PM-27) showed significant positive GCA effects similar with the findings of Tomar et al. (2017) ${ }^{[15]}$. The estimates of GCA effects revealed that out of 11 lines, 5 lines 
showed positive significant GCA effects for OC with the magnitude varied from 0.76 (SKM-1319) to 1.32 (SKM1033). Among the testers, none of the tester showed significant positive GCA effects. The estimates of GCA effects revealed that good general combiner line for NSS was SKM-1319. This line was also good general combiners for majority of yield and yield contributing traits viz., NSB, TW, HI and OC. With respect to quality traits, lines SKM-1013, SKM-939, SKM-1319 and SKM-1033 were found good general combiners for OC. Among the testers, the tester PM27 was considered good general combiner for SYP and BYP. The results of this study are in agreement with the findings of Singh et al. (2013) ${ }^{[11]}$. High general combining ability effects (GCA) were observed due to additive and additive $\mathrm{x}$ additive gene effects (Sprague and Tatum 1942) ${ }^{[13]}$.

\section{Estimation of Specific Combining Ability Effects}

Significant positive and negative SCA effects were recorded for all the observed traits (Table 4). Out of 33 crosses, three crosses viz., SKM-1013 x PM-28, SKM-1214 x Pusa Vijay and SKM-445 x Pusa Vijay exhibited significant SCA effects for SYP. In addition to this, these crosses exhibited significant SCA effects for various yield contributing charecters, viz., NPB, NSB, LMA, NSS, BYP and HI (Table 4). With respect to oil content maximum SCA effect for OC were expressed by cross SKM-1033 x PM-27 (3.68) followed by SKM-1013 x Pusa Vijay (2.61), SKM-1314 x PM-28 (2.15) and so on (Table 2) similar findings observed by Singh et al. $2013^{[11]}$ and Tomar et al. $2017^{[15]}$ for some traits in mustard.

Table 3: Estimates of GCA and SCA effects for fourteen characters in Indian mustard

\begin{tabular}{|c|c|c|c|c|c|c|c|c|c|c|c|c|c|c|c|}
\hline No. & Genotype & DOF & \begin{tabular}{|l|} 
DOM \\
\end{tabular} & PH & PB & NSB & LMA & NSP & LS & NSS & SYP & TW & BYP & HI & OC \\
\hline 1 & Pusa Vijay & .01 & 0.41 & 0.03 & 0.14 & 0.19 & $3.88 * *$ & $-28.37 * *$ & 0.06 & 0.24 & -0.46 & -0.06 & -1.88 & 0.38 & 0.27 \\
\hline 2 & & & & & & & & & 0.1 & & $23^{*}$ & & & & .12 \\
\hline $\mathrm{J}$ & & & & & & & & & & .27 & -0.77 & & & 81 & 0.15 \\
\hline 4 & & & & & & & -2.21 & & & & & & & 3 & .08 \\
\hline 5 & & 55 & $1 * *$ & 3.25 & 0.3 & 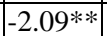 & $7.45 * *$ & & 0.11 & .58 & 1.44 & .21 & 1.34 & .1 & 35 \\
\hline 6 & & $3 * *$ & & 6.01 & $59 * *$ & 0.58 & $-4.48 *$ & 4.4 & .14 & $76^{*}$ & 1.56 & 0.1 & 05 & 0.27 & $02 \% *$ \\
\hline 7 & & $3 * *$ & $72 * *$ & -6.02 & 03 & .54 & $52 * *$ & 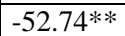 & 12 & 0.58 & $-2.78 * *$ & $0.38 * *$ & 5.4 & 10 ** & $=$ \\
\hline 8 & & $79 * *$ & $95 * *$ & $16.83 * *$ & 36 & $\mid-3.65 * *$ & $6.33 * *$ & 621 & 0.2 & .02 & -1.22 & $-0.91 * *$ & 86 & -1.93 & 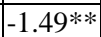 \\
\hline 9 & & $01 *$ & $.95 * *$ & $-9.39 *$ & .03 & $-1.98^{* * *}$ & 3.77 & -9.2 & 0.21 & $24 * *$ & $3.56^{* *}$ & $-0.69 * *$ & 0.17 & 60 ** & $.02 *$ \\
\hline 10 & & $23 * *$ & $28^{*}$ & 3.23 & .03 & $3.24 * *$ & 0.1 & -12.07 & $35 * *$ & $1.09 * *$ & 1.33 & $0.69 * *$ & .16 & $07 * *$ & $76 * *$ \\
\hline 11 & & 0.12 & .73 & 95 & $41 *$ & $0.91 * *$ & -0.26 & 35.1 & $44 * *$ & $91 * *$ & 56 & $0.32 *$ & 87 & 0.74 & -0.80 ** \\
\hline 12 & & 77 & $94 * *$ & 19 & 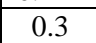 & & .27 & & $28^{*}$ & $09 * *$ & 1.67 & 0.2 & .38 & 39 & -0.47 \\
\hline 13 & & 68 & $.06 *$ & .0 & 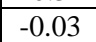 & $8 * *$ & $14^{*}$ & $2.82 *$ & -0.1 & 58 & 0.22 & $29 *$ & .05 & 15 & $.20 * *$ \\
\hline 14 & & $01 *$ & & & 4 & & $-17.36 * *$ & -4.9 & $29 * *$ & & -0.67 & $28 *$ & .7 & .82 & $32 * *$ \\
\hline 15 & $a_{2}$ & $23 * *$ & 41 & & & $36 * *$ & $-11.29 * *$ & 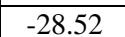 & \begin{tabular}{|l|}
$-0.46^{*}$ \\
\end{tabular} & 13 & $46 * *$ & 0.19 & 7.74 & 2.4 & -0.04 \\
\hline 16 & & 0.21 & $-2.19 *$ & 3.71 & 36 & & $9.17 *$ & & 0.01 & 91 & -0.54 & -0.33 & 5.91 & 1.84 & -0.67 \\
\hline 17 & & $1.66^{*}$ & 1.14 & \begin{tabular}{|l|}
-13.75 \\
\end{tabular} & -0.47 & $2.03 * *$ & -3.23 & 37. & 03 & 09 & -3.31 & $-0.75^{* *}$ & 1.99 & $-4.34 *$ & $2.61 * *$ \\
\hline 18 & & 1.32 & $59 * *$ & 021 & $03 *$ & & -2.89 & & 19 & 91 & -0.31 & -0.03 & -8.83 & 2.87 & 0.15 \\
\hline 19 & & -1.45 & -1.75 & -10.28 & $97 * *$ & $-1.75^{* * *}$ & 2.62 & 2 & 0.02 & 1.2 & $5.46^{* * *}$ & $1.15 * *$ & $14.78^{*}$ & 0.55 & -0.29 \\
\hline 20 & $V D$ & $2.43 * *$ & -008 & -496 & 0.64 & -0.75 & $-13.69 * *$ & & $0.85 * *$ & 20 & 1.69 & -0.49 & 2.34 & .54 & -0.33 \\
\hline 21 & & -0.34 & 0.25 & 331 & $0 ?$ & $-1.97 * *$ & -7.04 & -23 & $0.64 * *$ & & 0.58 & 0.08 & -6.76 & 4.25 & $1.08^{*}$ \\
\hline 22 & & $\mid-2.79 * *$ & $30 * *$ & .53 & $86^{*}$ & $1.70 * *$ & 4.99 & 888 & $0.46^{*}$ & & $-3.65^{*}$ & $0.59^{*}$ & 10.28 & $-8.30 * *$ & 0.74 \\
\hline 23 & & $2.32 * *$ & $4.03 * *$ & 12.57 & & 0.14 & 1.83 & -26.96 & 0.28 & $2.42 * *$ & -2.42 & -0.28 & -5.07 & -1.14 & $1.70 * *$ \\
\hline 24 & & $\mid-2.57 * *$ & $-2.30 *$ & -3.66 & -0.36 & -0.3 & $.19 * *$ & 140 & $0.47 *$ & 0.09 & -0.87 & -0.29 & $-14.51^{*}$ & $6.14 * *$ & $-2.17 * *$ \\
\hline 25 & & & & & 99 & $\mid-2.30 * *$ & $33^{*}$ & $J^{*}$ & $.76 * *$ & 80 & $\begin{array}{l}-2.09 \\
\end{array}$ & .54* & 3.93 & -3.72 & $-2.78 * *$ \\
\hline 26 & & $2.68 * *$ & 01 & & & & 4.59 & ** & 0 & & 57 & 0.12 & -7.72 & 3.17 & -0.06 \\
\hline 27 & & $\mid-2.88^{* * *}$ & $3.57 * *$ & & $2 \%$ & & 201 & & 028 & 52 & $5.10^{* * *}$ & 0.28 & 7.24 & $.00^{* * *}$ & $1.17^{*}$ \\
\hline 28 & & $-2.10 *$ & -1.43 & & & & $10.05^{*}$ & $8.08^{*}$ & $-0.66^{* *}$ & $-2.48 * *$ & -3.01 & $1.05 * *$ & 42 & -3.33 & -0.71 \\
\hline 29 & & & $99 * *$ & & & & 5.28 & & & & & -0.43 & 27 & -2.74 & $1.66 * *$ \\
\hline 30 & & $79 * *$ & & 12.44 & $18^{* *}$ & & 17 & & $57 * *$ & & & $\Omega_{1}$ & & & 0.59 \\
\hline 31 & & & & & & & & & -0.03 & & $-4.68^{*}$ & & 1.19 & $4.52 *$ & -0.16 \\
\hline 32 & & & & & & & & & $-0.74 * *$ & & $4.21 *$ & & & 3.59 & $2.37 * *$ \\
\hline 33 & & & & & & $-3.03^{* *}$ & & $41.70 *$ & & & 0.99 & $-0.74 * *$ & .51 & & 0.03 \\
\hline 34 & & & & -2.74 & & & & & & & & $0.74 * *$ & 9.49 & $-5.04 *$ & -0.52 \\
\hline 35 & & & & & & $1.70 * *$ & 54 & & & & & & 6 & $-6.28 * *$ & 0.02 \\
\hline 36 & & & & & & & 7.26 & & & -0.04 & $4.55^{*}$ & \begin{tabular}{|l}
$-0.62 *$ \\
\end{tabular} & $\begin{array}{l}-0.38 \\
\end{array}$ & $4.76^{*}$ & $3.68^{* * *}$ \\
\hline 37 & & & & & & $.00 * *$ & & 12 & $0.47^{*}$ & 17 & $-4.90^{* *}$ & 0.07 & -0.01 & $-5.57 *$ & 0.1 \\
\hline 38 & & $77 * *$ & & & & & 0.91 & & & & $-4.57 *$ & \begin{tabular}{|l}
$0.61 *$ \\
\end{tabular} & $13.15^{*}$ & $-9.84 * *$ & -0.49 \\
\hline 39 & & & & & & $-3.00^{* * *}$ & 13.28 *** & 1 & $63 * *$ & $2.39 * *$ & $6.32 * *$ & -0.3 & -2.42 & $7.66^{* *}$ & -1.90 ** \\
\hline 40 & & & & & & -2.5 & 2 & -1 & & 0.39 & 1.9 & 0.46 & .55 & -0.13 & $1.51 * *$ \\
\hline 4 & & & & & & & & & & & $-5.23 * *$ & $-1.33^{* *}$ & 55 & 57 & \\
\hline 4 & & & & & & & 9 & & & & 2.99 & 0.12 & -1.16 & 3.98 & 0.49 \\
\hline 43 & & & & & & & & & & & $-4.79 * *$ & & 5.69 & $-7.84 * *$ & $1.29 *$ \\
\hline 44 & & & & & & & & & & & & & .79 & & \\
\hline 45 & & $2.56 * *$ & -3.15 & & & & & & & & & 47 & -4.42 & $6.18 * *$ & $-1.18^{*}$ \\
\hline 4 & & & & & & & & & w & & $4.43^{*}$ & & & 0.14 & $2.15 *$ \\
\hline$\overline{47}$ & M-28 & .44 & 15 & 3. & 0.66 & $2.00 * *$ & $16.58^{\prime}$ & & 0. & $\rho_{2}$ & -2.45 & 0.08 & -3.55 & -1.04 & -0.89 \\
\hline
\end{tabular}

*,** Significant at $5 \%$ and $1 \%$ level of significance, respectively;

$\mathrm{DOF}=$ Days to $50 \%$ flowering; $\mathrm{DOM}=$ Days to maturity; $\mathrm{PH}=$ Plant height; $\mathrm{NPB}=$ Number of primary branches per plant; $\mathrm{NSB}=\mathrm{Number}$ of secondary branches per plant; LMA= Length of main axis; NSP= Number of siliquae per plant; LS= Length of siliqua; NSS= Number of seeds per siliqua; SYP= Seed yield per plant; TW=1000-Seed weight; $\mathrm{BYP}=$ Biological yield per plant; $\mathrm{HI}=$ Harvest index; $\mathrm{OC}=\mathrm{Oil}$ content 


\section{Conclusion}

The significant differences observed among the genotypes for all the characters studied indicated the presence of large amount of genetic variability among the inbred lines, the OPVs, and their crosses, which is a prerequisite in the establishment of a successful breeding programme. The significant mean squares for line $\mathrm{x}$ testers indicated significant contribution of hybrids for specific combining ability variance components. These results suggested the existence of additive and non-additive gene actions for various traits in the material studied. Line SKM-1319 and SKM-1314 have been found good general combiner for majority of traits so that both the lines are parents of the higher yielding crosses viz., SKM1319 x PM-27 and SKM-1314 x PM-28. Thus, lines SKM1319, SKM-1314 and SKM-1033 can be utilized in hybridization programme for developing a variety by exploiting non-additive gene action.

\section{Conflicts of Interest}

The authors declare no conflicts of interest regarding the publication of this paper.

\section{References}

1. Directorate of Economics and Statistics, Agricultural Statistics at a Glance 2018. Ministry of Agriculture \& Farmers Welfare, Government of India http:// eands.dacnet.nic.in, 2018.

2. Bhowmik B, Mitra B, Bhadra K. Diversity of insect pollinators and their effect on the crop yield of Brassica juncea L., NPJ-93, from Southern West Bengal. International Journal of Recent Scientific Research, 2014; 5(6):1207-1213.

3. Chaurasiya JP, Singh M, Yadav RK, Singh L, Yadav HC. Genetic analysis for estimates components of genetic variance in Indian mustard (Brassica juncea (L.) Czern \& Coss). The Pharma Innovation Journal. 2018; 7(2):104107.

4. Gupta SK, Karuna N, Dey T. Heterosis and Combining Ability in Rapeseed (Brassica napus L.). J Res. Skuast, 2006; 5(1):42-47.

5. Kempthorne O. An introduction to genetical statistics. John Willey and Sons Inc., New York, 1957, 323-331.

6. Kumar R, Singh M, Tomar A. Combining ability (GCA and SCA) and heterotic response analysis in Indian mustard (Brassica juncea (L.) Czern and Coss). International Journal of Applied Research, 2017; 3(8):719-724.

7. Meena HS, Kumar A, Ram B, Singh VV, Meena PD, Singh BK et al. Combining Ability and Heterosis for Seed Yield and Its Components in Indian Mustard (Brassica juncea L.). Journal of Agricultural Sciences and Technology. 2015; 17:1861-1871.

8. Nagaharu U. Genome analysis in Brassica with special reference to the experimental formation of B. napus and peculiar mode of fertilization. Japan Journal of Botany. 1935; 7:389-452.

9. Patel A, Prajapati KP, Patel PJ, Shah S, Patel PS. Genetic studies of yield and quality traits in Indian mustard [Brassica juncea (L.) Czern and Coss.]. Journal of Oilseed Brassica, 2015; 6(2):289-295.

10. Rambhajan, Chauhan YS, Kumar K. Natural cross pollination in Indian mustard. Cruciferae Newsletter. 1991; 14(15):24-25.

11. Singh AK, Manibhushan, Bhatt BP, Singh KM, Upadhyaya A. An analysis of oilseeds and pulses scenario in eastern India during 2050-51. Journal of Agricultural Sciences. 2013; 5(1):241-9.

12. Soxhlet F. The weight analysis determination of milk fat. Dingler's Polytechnical Journal. 1879; 232:461-465.

13. Sprague GH, Tatum LA. General v/s specific combining ability in single crosses in corn. Journal of American Society of Agronomy. 1942; 30:923-932.

14. Teklewold A, Becker HC. Heterosis and combining ability in a diallel cross of Ethiopian mustard inbred lines. Crop Science. 2005; 45(6):2629-2635.

15. Tomar A, Singh M, Singh SK. Combining Ability (SCA \& GCA) and Heterotic response analysis in Indian mustard (Brassica juncea L. Czren \& Coss). Journal of Pharmacognosy and Phytochemistry. 2017; 6(4):19992004.

16. Tyagi PK, Singh R. Rapeseed and Mustard: Breeding Objectives of Rapeseed and Mustard. LAP LAMBERT Academic Publishing, 2016, 232.

17. Vaughan JG. A multidisciplinary study of the taxonomy and origin of brassica crops. Bio Science. 1977; 27(1):35.

18. Wolko J, Dobrzycka A, Bocianowski J, BartkowiakBroda I. Estimation of heterosis for yield-related traits for single cross and three-way cross hybrids of oilseed rape (Brassica napus L.). Euphytica. 2019; 215:156. 